\title{
HBG1 Gene
}

National Cancer Institute

\section{Source}

National Cancer Institute. HBG1 Gene. NCI Thesaurus. Code C84955.

This gene plays a role in the transport of oxygen to tissues of the body in the fetus and neonate. 